Received: 29/05/2019

Revision: 09/01/2020

Accepted: 14/01/2020

OnlineFirst:11/04/2020

\title{
Validity and Practicality of the Biotechnology Series Learning Model to Concept Mastery and Scientific Creativity
}

\section{Iwan Wicaksono}

Dr., Faculty of Teacher Training and Education, University of Jember, Jember, Indonesia, iwanwicaksono.fkip@unej.ac.id

\section{Supeno}

Dr, Faculty of Teacher Training and Education, University of Jember, Jember, Indonesia, supeno.fkip@unej.ac.id

\section{Aris Singgih Budiarso}

M.Pd, Faculty of Teacher Training and Education, University of Jember, Jember, Indonesia, singgiharis.fkip@unej.ac.id

The BIOSEL (Biotechnology Series Learning) model is a learning model that provides opportunities for students to assemble learning through a conceptual description of the coherent and precise steps of Biotechnology implementation. The purpose of this research was to analyze validity and practicality of the BIOSEL model to improve the concept mastery and scientific creativity of junior high school students. This research was conducted in the Odd Semester of the 2018/2019 Academic Year at Ex Residency of Besuki Junior High Schools (Jember, Banyuwangi, Bondowoso, and Situbondo) which involved 140 junior high school students of class XI through purposive sampling. The validity instruments used were validation sheets for learning and material content experts and for user. Meanwhile, the practicality instrument used was an observation sheet focusing on learning implementation, relevant student activities, and obstacles found during learning. The results of BIOSEL model validity showed that the model had the content, construct, and face validities that had fulfilled the feasibility to apply in the learning process. In addition, the results of BIOSEL model practicality included implementation of each syntax with an average value of $<3.6$ as a very good category, student activities with an average value of $<85 \%$ as a very active category, and the obstacles found that had the appropriate alternative solutions.

Keywords: BIOSEL model, validity, practicality, concept mastery, scientific creativity

Citation: Wicaksono, I., Supeno, \& Budiarso, A. S. (2020). Validity and Practicality of the Biotechnology Series Learning Model to Concept Mastery and Scientific Creativity. International Journal of Instruction, 13(3), 157-170. https://doi.org/10.29333/iji.2020.13311a 


\section{INTRODUCTION}

The characteristics of natural science learning is more emphasis on the process approach. This approach encourages students to discover facts and to build concepts, theories and scientific attitudes so as it is expected to have a positive effect towards the quality of educational processes and products (Maxwell, 2004). An important component in natural science learning is that the learning can be understood through steps of observation, problem formulation, preparation of hypothesis, testing hypothesis through experiments, making conclusions, and concept discovery. Furthermore, natural science learning can be interpreted as follows: (1) observe what is happening; (2) understand what is being observed; (3) use new knowledge to predict what is happening; and (4) test the hypothesis to seek the truth (Mayer, 2011; National Research, 2007).

The application of natural science learning will succeed if supported by a learning model that can make students easily understand the material being taught. Learning models play an important role in the learning process because they are able to describe systematic procedures in organizing student learning experiences to achieve learning goals (Baumfalk et al., 2019; Wehmeyer et al., 2012). The selection of learning models requires consideration of student characters and the material taught in order to provide a greater chance of success. The role of teacher as a facilitator is very important to encourage student-centered learning (Hines et al., 2019). The proper process of transferring knowledge enables students to have the ability of mastering the material concepts correctly.

Concept mastery in the form of cognitive ability becomes one of the important aspects to measure the success of natural science learning. The process of mastering the natural science concepts can be successful when students can simplify abstract materials to be more easily understood, it provides interpretation, and is applicable in daily life (Baumfalk et al., 2019). Mastery of correct natural science concepts result in the emergence of creative ideas from students (Cherif et al., 2016). Students who think creatively are equipped with the ability to create new thoughts and products that can be useful in their lives. The categories of student creativity vary depending on the experience and knowledge they have (Roy, 2016).

Junior high school curriculum contain Biotechnology material aimed at encouraging students to have appropriate concept mastery which is potential to bring up scientific creative ideas that can be applied in everyday life. Biotechnology has characteristics as a multidisciplinary science and quite applicative which requires appropriate concept mastery (Goh \& Sze, 2019; Nordqvist \& Aronsson, 2019). The development of science and technology makes Biotechnology material one of the fields of natural science that must be mastered by junior high school students because this material is directly related to everyday life. This Biotechnology material continues to evolve over time in line with the needs of 21 century skills characterized by increased creativity demands, persistence and problem solving through group work. 
The implementation of natural science learning process indicates a less encouragement of increasing concept mastery and scientific creativity of students (Wicaksono, 2017). Preliminary research that has been done in three junior high schools in Jember Regency with the samples consisting of one teacher and three students supported the indication. Some of the results obtained were that the students tended to memorize concepts because of the teacher-centered learning applied and the absence of learning model that encouraged the students' scientific creativity either in giving opportunities or creating Biotechnology products which gave benefits in life. Besides, the absence of discussion and experiment activities caused lack of students' mastery of Biotechnology material and scientific creativity. The results showed that the concept mastery was low because the teacher only relied on memorizing the material from the textbook in the learning process and the students were not trained to think creatively when conducting an experiment (Wechsler et al., 2018).

The development of natural science learning model is oriented to student involvement in discussion and learning activities. The development needs to be done to facilitate teacher in presenting the subject matters and in optimizing student learning outcomes. The science learning models that have been used previously to improve concept mastery and scientific creativity are Guided Inquiry (GI) model and Project Based Learning model (PjBL). Further analysis of the advantages and disadvantages of applying these two models revealed that Guided Inquiry (GI) model was able to increase students' conceptual power indicated by the experimental class' average score of 82.5 compared to the control class with an average score of 75 (Yohana et al., 2018). Besides, the Project Based Learning (PjBL) model was able to improve students' scientific creativity as indicated by the experimental class' mean value of 80 compared to the control class with an average score of 69.5 (Chu et al., 2017). On the other hand, the analysis of both models showed the disadvantages that GI model required longer periods of time when students processed discoveries and information gathering of Biotechnology material (Ketpichainarong et al., 2010). This might result in a sense of hesitation for conducting activities that made learning objectives were often not achieved. The lack of application of PjBL model showed that students who had weaknesses in the experiment and gathering information on Biotechnology material would have difficulty in finding creative ideas (Jatmiko et al., 2018). These aforementioned analyses provide an opportunity to develop a new learning model that is able to improve concept mastery and scientific creativity in Biotechnology material.

The BIOSEL (Biotechnology Series Learning) model is a learning model used to teach Biotechnology material to improve students' concept mastery and scientific creativity. This model was developed based on a needs analysis, the advantages and disadvantages of GI and PjBL models, and the expectations of the model development goals. The BIOSEL model provides opportunities for students to assemble learning through the description of the right concepts and steps for implementing Biotechnology that can provide a unified concept mastery and scientific creativity of students. The syntaxes in the application of BIOSEL model are: identifying problems, constructing information, conducting an experiment, analyzing experimental results, elaborating creativity, and reflecting. The syntaxes are compiled by taking into account the characteristics of 
Biotechnology material that uses living things and the processes within them to produce certain products. If the BIOSEL model syntaxes are implemented properly, the opportunities for students' concept mastery and scientific creativity will increase.

\section{METHOD}

This type of research was educational design research (Plomp, 2013), design, develop and evaluate educational interventions (such as programs, strategies and learning materials, products, and systems) as a solution to solving complex problems in educational practice, which also aims to advance our knowledge of the characteristics of these interventions and their design and development processes. Using steps adapted from the development model included: the preliminary research, designing, developing initial product, initial field try-out, major product revision, major field try-out, operational product revision, operational field try-out, final product revision, and product dissemination (Borg et al., 2003). The results of validity and practicality of the BIOSEL model were a series of steps to revise the main product.

This research was conducted on the Odd Semester of the 2018/2019 Academic Year at Ex Residency of Besuki Junior High Schools (Jember, Banyuwangi, Bondowoso, and Situbondo) on 140 junior high school students in class XI. The research sampling technique was a purposive sampling.

The instrument used to test validity of the BIOSEL model was the validation sheets while for testing the practicality, a learning observation sheet was used. Specifically, the types of research instruments to test the validity of BIOSEL model were expert validation sheets for learning and material content and user. Additionally, the instrument of BIOSEL model practicality was an observation sheet focusing on learning implementation, relevant student activities, and obstacles found in using BIOSEL model during the learning process.

Data analysis technique for validity of the BIOSEL model used average score with the categories as follows: very valid $(80.26 \%<\mathrm{x} \leq 100 \%)$, valid $(62.6 \%<\mathrm{x} \leq 80.25 \%)$, less valid $(43.76 \%<x \leq 62.5 \%)$, and invalid $(25 \%<x \leq 43.75 \%)$ (Aryadoust \& Raquel, 2019). When the validation result reached a value of $\geq 60 \%$, this indicated that the development of BIOSEL model product was feasible to develop further into the next stage.

The data analysis technique of the practicality of BIOSEL model was the learning implementation based on the results of three observers' observations of the model syntaxes which included: identifying problem, constructing information, conducting an experiment, analyzing experimental results, elaborating creativity, and reflecting. Furthermore, the categories for the learning implementation consisted of: $3.6 \leq$ excellent $<4.0 ; 2.6 \leq \operatorname{good}<3.5 ; 1.6 \leq$ poor $<2.5$; and $1.0 \leq$ very poor $<1.5$ (Mustami et al., 2019). Meanwhile, data regarding relevant student activities were analyzed based on the frequency of activities that appeared during each 5 minutes, thus it could determine the average score of student activities which included reading teaching material, understanding information, conducting experiment, analyzing data, following up on findings, and concluding the findings. The categories indicated by the average score of student activities were as follows: $85 \% \leq$ very active $<100 \% ; 70 \% \leq$ active $<85 \%$; 
$60 \% \leq$ less active $<70 \%$; and $25 \% \leq$ not active $<60 \%$ (Zhang et al., 2008). Then the observation data related to the obstacles found during the learning process using the BIOSEL model were analyzed based on the accuracy of relevant alternative solutions to support students' concept mastery and scientific creativity.

\section{FINDINGS}

The BIOSEL model had been validated by three experts, each of them was learning, material content, and the user. The results of validation evaluation of BIOSEL model reached the average value of $\geq 60 \%$. In conclusion, the model development product was valid and could be developed into the next stage. The mean validation score of BIOSEL model are shown in Table 1.

Table 1

Results of the BIOSEL Model Validation

\begin{tabular}{lll}
\hline Aspect & Average Score & Category \\
\hline A. Content Validity & & \\
\hline - Needs Analysis & $83 \%$ & Very Valid \\
\hline - Suitability with Current Knowledge & $78 \%$ & Valid \\
\hline B. Construct Validity & & \\
\hline - Model Rationality & $84 \%$ & Very Valid \\
\hline - Theoretical and Empirical Support & $81 \%$ & Very Valid \\
\hline - Components of Planning and Model Implementation & $76 \%$ & Valid \\
\hline - Learning Environment of the Model & $86 \%$ & Very Valid \\
\hline - Model Assessment and Evaluation & $83 \%$ & Very Valid \\
\hline C. Face Validity & & \\
\hline - The Truth of Concepts & $86 \%$ & Very Valid \\
\hline - Principles in Measurement & $82 \%$ & Very Valid \\
\hline - Instrument Format & $78 \%$ & Valid \\
\hline - Language & $90 \%$ & Very Valid \\
\hline
\end{tabular}

Table 1 shows that the content validity including needs analysis and suitability with current knowledge have the average scores of $83 \%$ and $78 \%$, and are categorized as very valid and valid respectively. In addition, the construct validity which includes rationality model, theoretical and empirical support, components of the planning and model implementation, learning environment of the model, model assessment and evaluation have the average scores of $84 \%, 81 \%, 76 \%, 86 \%$, and $83 \%$ respectively. They are categorized as very valid and valid. Furthermore, the face validity includes truth of concept, principles in measurement, instrument format and language respectively obtain the average scores of $86 \%, 82 \%, 78 \%$, and $90 \%$, included in very valid and valid categories. Based on the validation results in Table 1, it can be concluded that the BIOSEL model developed had met the content, construct, and face validities and thus could be applied in the learning process.

The observation data related to the learning implementation of BIOSEL model are based on application of each model syntax as follows: identifying problem, constructing information, conducting an experiment, analyzing experimental results, elaborating 
creativity, and reflecting. The average scores of the model implementation in each class are shown in Table 2.

Table 2

Implementation of BIOSEL model learning

\begin{tabular}{llllllll}
\hline Syntax & K1 & K2 & K3 & K4 & K5 & K6 & Mean \\
\hline 1 & 3.2 & 3.1 & 3.3 & 3.3 & 3.6 & 3.5 & 3.3 \\
\hline 2 & 3.5 & 2.9 & 3.8 & 3.0 & 3.4 & 3.5 & 3.4 \\
\hline 3 & 3.4 & 3.0 & 3.6 & 3.2 & 3.7 & 3.4 & 3.4 \\
\hline 4 & 3.4 & 2.9 & 3.4 & 3.0 & 3.9 & 3.3 & 3.3 \\
\hline 5 & 3.2 & 3.3 & 3.6 & 3.1 & 3.7 & 3.8 & 3.5 \\
\hline 6 & 3.8 & 3.0 & 3.5 & 2.8 & 3.5 & 3.6 & 3.4 \\
\hline
\end{tabular}

Note: (1) identifying the problem; (2) constructing information; (3) conducting an experiment; (4) analyzing experimental results; (5) elaborating creativity; and (6) reflecting.

Table 2 shows that the learning implementation of BIOSEL model has the average scores of syntaxes for identifying the problem at 3.3; constructing information at 3.4; conducting an experiment at 3.4; analyzing experimental results at 3.3; elaborating creativity at 3.5; and reflecting at 3.4. These data indicated that the BIOSEL model syntaxes were categorized as very good in the learning process.

The learning process of BIOSEL model involved the student activities. The observers' assessment on the student activities was carried during a 5 minute period in order for the data regarding student activities could be gained including: reading the teaching material, understanding the information, conducting the experiment, analyzing the data, following up on the findings, and concluding the findings. The average scores of the student activities during the learning process are displayed in Figure 1.

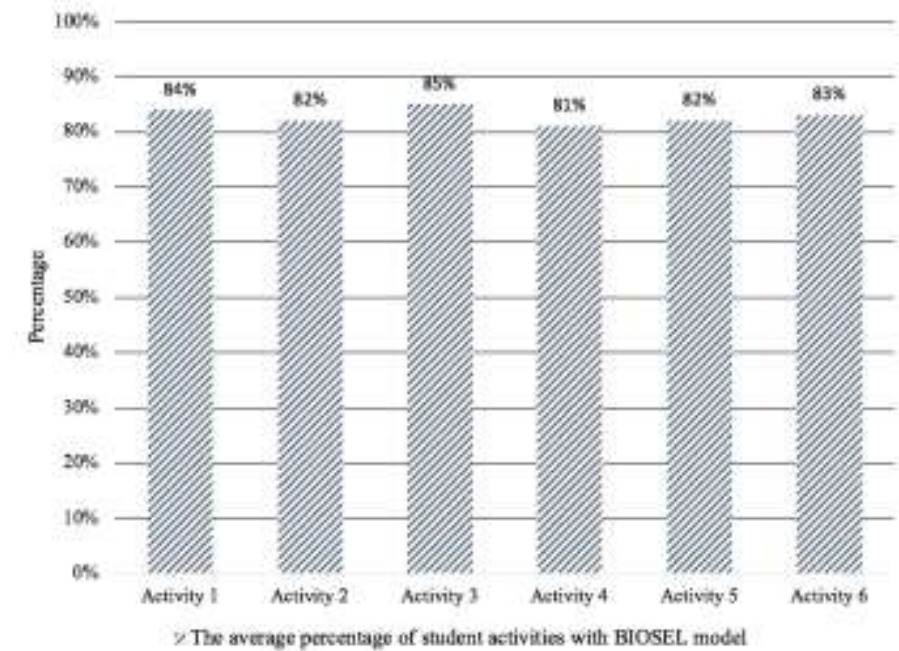

Figure 1

Data of Student Activities with BIOSEL Model

International Journal of Instruction, July $2020 \bullet$ Vol.13, No.3 
Note: Activities (1) reading the teaching material; (2) understanding the information; (3) conducting the experiment; (4) analyzing the data; (5) follow up on the findings; and (6) concluding the findings.

Figure 1 shows that there are six student activities during the learning process using BIOSEL model. The average percentage score for reading material activity was $84 \%$, understanding information activity was $82 \%$, conducting experiment activity was $85 \%$, analyzing data activity was $81 \%$, following up on findings activity was $82 \%$, and concluding findings was $83 \%$. These results indicated that the students were classified as active during learning process using the BIOSEL model.

In the process of learning implementation using BIOSEL model, the teachers found some obstacles which required alternative solutions. The alternative solutions were expected to facilitate the learning process. Here is the list of obstacles and alternative solutions given as shown in Table 4 .

Table 4

Obstacles and Alternative Solutions to BIOSEL Model

\begin{tabular}{lll}
\hline No. & Obstacles & Alternative Solutions \\
\hline 1. & $\begin{array}{l}\text { There were some students who were less } \\
\text { interested in carrying out Biotechnology } \\
\text { experiment activity. }\end{array}$ & $\begin{array}{l}\text { The teachers motivated students through } \\
\text { demonstration in implementing Biotechnology } \\
\text { experiments that made easier to understand. }\end{array}$ \\
\hline 2. & $\begin{array}{l}\text { There were few problems that could } \\
\text { encourage students to have creative } \\
\text { solutions. }\end{array}$ & $\begin{array}{l}\text { The teachers provided everyday-related problems to } \\
\text { make students contribute creative ideas to find the } \\
\text { solutions. }\end{array}$ \\
\hline 3. & $\begin{array}{l}\text { Some student groups did not understand } \\
\text { the function of the equipment and } \\
\text { materials for Biotechnology experiment. }\end{array}$ & $\begin{array}{l}\text { The teachers explained the functions of equipment } \\
\text { and materials needed for Biotechnology experiment. }\end{array}$ \\
\hline 4. & $\begin{array}{l}\text { Students still had difficulty in conducting } \\
\text { data analysis on Biotechnology } \\
\text { experiment. }\end{array}$ & $\begin{array}{l}\text { The teachers provided clear direction through } \\
\text { explanations of variables and data obtained during } \\
\text { Biotechnology experiment. }\end{array}$ \\
\hline
\end{tabular}

Table 4 shows that there were several obstacles found during the learning process of BIOSEL model. These obstacles were the low interest of students in carrying out the experiment, the need for creative ideas for solutions, understanding of the functions of tools and materials, and the process of conducting experimental data analysis. Based on these problems, alternative solutions were necessarily offered, namely the teachers should give a demonstration of experiment, provide issues related to students' daily life, explain the functions of tools and materials, and give explanation about the obtained variables and data.

\section{DISCUSSION}

\section{Validity of the BIOSEL Model}

Based on the data in Table 1, the results of expert and user validation on the BIOSEL model was categorized as valid, including content, construct, and face validities. These results indicated that the BIOSEL model was feasible in the learning process. The syntaxes of BIOSEL model contributed to steps that could increase the students' creativity and concept mastery. The syntax of conducting an experiment encouraged the students to follow up the series of information obtained, thus they could design the 
experimental steps (Katok, 2018). In addition, the syntax of elaborating creativity required the students to understand and to solve problems from different perspectives as a follow-up of their findings (Wicaksono, 2017). Each syntax of the BIOSEL model aimed to improve students' concept mastery and scientific creativity on Biotechnology material. The research results showed that when the learning process took place, it was necessary to provide opportunities for the students to express their creative ideas through experiment activity (Diwakar et al., 2019). Such activity could measure how far students understand the material being taught.

The criteria of content validity of the BIOSEL model that had been assessed were categorized as valid. One of them was a needs analysis to find out the shortcomings of the learning model that had been used. Stages of the needs analysis need to be done in the process of developing learning model in order to ensure that the product developed is the solution to the problems that occur (Sandoval, 2014). The results of needs analysis used to develop learning model will provide opportunities for the realization of relevant product.

Meanwhile, the criteria of construct validity included model rationality, theoretical and empirical support at each stage of the model, components of planning and model implementation, learning environment of the model, and assessment and evaluation of the model (Plomp, 2013). The BIOSEL model developed had been in accordance with the characteristics of the junior high school curriculum used, namely the revised edition of the 2013 curriculum. The syntaxes of the BIOSEL model included the stages of student-centered learning that encouraged the students to find fundamental concepts. The results of this research indicated that the experiment activity provided opportunities for the students to find solutions to a given problem.

Here is the description of student and teacher activities in the application of the BIOSEL model syntaxes, (1) the students tried to identify the problem given by the teachers and found some necessary information; (2) the students in groups arranged information in the form of story pictures telling about Biotechnology material; (3) the students followed a series of information obtained through an experiment and input the results into an observation table; (4) the students analyzed the experimental results and the data in order to answer the questions given; (5) the students gave alternative examples related to the findings; and (6) the students concluded the scientific concepts and ideas used in the Biotechnology learning process.

The learning environment of the BIOSEL model directed the students to conduct experiment in order to obtain solutions to the problems given. To support the implementation of learning model, learning environment must be designed properly to allow students to conduct an investigation for resolving problems found to make the learning becomes meaningful (Herrington et al., 2014; Lin-Siegler et al., 2016). In regards to the assessment and evaluation of learning in the BIOSEL model, a test instrument was occupied to measure the students' concept mastery and an observation sheet was used to measure the students' creativity during the learning.

The criteria of face validity also was categorized as valid, including the truth of concepts, principles in measurement, instrument format, and language (Moulton et al., 
2019). The format used in the validation sheets had been understood by the validators. This was supported by the statement in the validation sheets that made the validators easy to validate and to give input to the BIOSEL model. In addition, the language used in the BIOSEL model syntax had fulfilled the rules of language spelling system. The results of this research showed that the face validity assessment procedure provided the feasibility of item content through a qualitative assessment by the validators (Orr et al., 2018). Then this procedure produced a measure of the strong or weak agreement among the experts who assessed the feasibility of a measurement scale. The results of expert and user validation declared that the BIOSEL model was valid, hence it was necessary to test the practicality on concept mastery and scientific creativity.

\section{Practicality of the BIOSEL Model}

It focused on testing the learning implementation, relevant student activities to the learning model, and the obstacles found as well as their alternative solutions when carrying out the learning process. Based on the data in Table 2, in the learning implementation using the BIOSEL model the syntax with the highest average score was elaborating creativity with 86.2 . In the syntax, the students were given the opportunity to express their own solutions for the Biotechnology problems given as a follow up of the findings (Kim et al., 2016). Problems in the Biotechnology material would bring up original scientific ideas and students' concept mastery would increase (Helms et al., 2016). Based on the theory of creativity, creating a learning environment can enhance students' creative ideas through the opportunities given to students to think divergently (Sternberg, 2018). This theory is important to be applied in the learning process because it is able to support the learning process and to increase students' understanding of the material being taught. The results showed that the form of the learning environment was the students were given the freedom to explore, to imagine, and to bring creative ideas regarding the material taught by teacher (Hawley, 2018). As viewed from the theory of students' mastery of cognitive concepts, teacher must direct students to important concepts that need to be learned so that students can remember the information and apply it in daily life (Suandi et al., 2018). In this research, the implementation of the whole syntaxes of BIOSEL model, especially experiment and provision of different problems as a follow-up of students' findings was able to improve students' concept mastery.

The implementation of this BIOSEL model could not be separated from studentcentered syntax. The identifying the problem syntax directed the students to identify problems given by the teachers. The process of identifying problems was the initial stage of mastering problem where an object in a particular situation could be recognized as a problem. The research results showed that problem recognition could encourage the idea of solutions for the problems around (Erlina et al., 2018). The teachers encouraged the students to identify useful problems and found alternative solutions to the complex problems. Scientific methods could be used to identify problems to give the students potential to produce the right problem solving. Besides, the constructing information syntax enhanced the students to understand a new set of information in the form of storytelling pictures. The research results revealed that the process of connecting new 
information with the understanding possessed by the students could construct new knowledge that could be used to solve the problems found (Glynn \& Duit, 2012). The conducting experiment syntax directed the students to carry out the steps of Biotechnology experiment. The experiment provided opportunities for the students to understand new material and look for explanations of why it happened. The results of the research indicated that when the experiment was going on, the teacher had the task to guide the students to conduct the experiment based on the scientific method in order to obtain valid experimental results and suitable with existing theories (Hwang et al., 2009). The syntax of analyzing experimental results aimed to train the students to analyze data based on the results of Biotechnology experiment carried out and to answer several questions based on the data obtained. The results of the research showed that the activity of analysis could train the students' creative thinking skills in solving a problem (Taconis et al., 2001). The elaborating creativity syntax also led the students to understand the problems in different situations as a follow-up to the results of Biotechnology experiment conducted. The results of creativity product emphasized that what was produced from the process of creativity was something new, original, and meaningful. Thus, the students must be prepared to survive through provision of communication skills, action, and creativity. The results of the research showed that the teacher's elaboration activities needed to adjust the learning environment in a condition that could facilitate the students to develop their creativity so that the potential in students could be explored optimally (Wicaksono, 2017). The students needed to understand new concepts or new relationships between ideas that they already had. The idea was used to solve various kinds of problems that existed in the environment around them. Then the reflecting syntax directed the students to conclude concepts and scientific ideas that had been used in the learning process. This reflection activity aimed to provide understanding of the process and results of concept mastery and scientific creativity in the learning process. Reflection allowed the students to think ideas more varied and helped process the experience, and the results they got would be better. The results of the research revealed that reflection could compare the experience that had been obtained by other students to be used for an advanced material as an additional (Dai, 2019).

Based on Table 3, there were six student activities observed, including reading the teaching material, understanding the information, conducting the experiment, analyzing the data, following up on the findings, and concluding the findings. The experiment activity gained the highest average percentage score at $85 \%$ that was categorized as very active. Conducting experiment grew the students' creative thinking skills that allowed the students to express the knowledge that had been previously possessed in the Biotechnology experiment steps. The results of the research showed that through experiment activity, the students had direct experience in learning and proved the presence or absence of a gap between the theories that had been studied and the practices carried out (Jatmiko et al., 2016). The concept mastery after the experiment activity could be followed up with different problems to foster the students' creative thinking skills. The students' activeness was encouraged through the process of expressing creative ideas to solve different problems in real life (Swarat et al., 2012). 
The application of the BIOSEL model was certainly inseparable from the problems found in the class, such as some students were less interested in carrying out the Biotechnology experiment that required the teachers to motivate them through demonstration. It is important that students have learning motivation in order for the conducive learning process in the classroom will take place (Wicaksono et al., 2015). In the aspect of motivation, the teachers played an important role in creating a climate and positive attitude that encouraged the success of student learning. Presentation of the problem became an important factor in encouraging them to express creative solutions. A problem causes an individual to try to solve the problem at hand using various ways such as thinking, trying, and asking to solve the problem. One indicator of concept mastery in the BIOSEL model was that the students must be able to understand the function of Biotechnology experiment tools and materials to avoid failure as well as need to know the variables that must be controlled. In addition, the students were still constrained in conducting Biotechnology experimental data analysis, thus direction through explanations of variables and data needed to be provided for students. Data analysis is useful in compiling findings from various sources of data collection because it is very helpful in solving a problem (Scanlon et al., 2004).

\section{CONCLUSION}

Based on the above research results and discussion regarding validity and practicality of the BIOSEL model to improve the concept mastery and scientific creativity of junior high school students, some conclusions are drawn. Based on the expert and user validation results, validity of the BIOSEL model to improve the concept mastery and scientific creativity of junior high school students achieved an average score of $\geq 60 \%$ categorized as valid, including content, construct, and face validities. Therefore, it was feasible to be apply in the learning process. Meanwhile, practicality of the BIOSEL model to improve the concept mastery and scientific creativity of junior high school students were as follows: (1) implementation of each syntax of the BIOSEL model had an average score of $<3.6$, categorized as very good; (2) Relevant student activities to the BIOSEL model had an average score of $<85 \%$, categorized as very active; and (3) obstacles found during the learning process using the BIOSEL model had the appropriate alternative solutions that they could support students' concept mastery and scientific creativity.

The implication of this research is that the BIOSEL model is suitable for Biotechnology material learning process that needs the right mastery so that students have the ability to make decision about which Biotechnology is good and have creativity to overcome the risks. This BIOSEL model still requires further effectiveness testing through description of concept about the steps of Biotechnology implementation that describes a unity coherently and appropriately.

\section{ACKNOWLEDGEMENTS}

Our gratitude goes to the Institute for Research and Community Service of University of Jember through a Research Grant Support Islamic Development Bank program for funding this research completion. Our thanks also go to the Ex Residency of Besuki 
Junior High Schools (Jember, Banyuwangi, Bondowoso, and Situbondo) that have provided opportunities to carry out this research at their schools.

\section{REFERENCES}

Aryadoust, V., \& Raquel, M. (2019). Quantitative data analysis for language assessment volume I: Fundamental techniques. London: Routledge.

Baumfalk, B., Bhattacharya, D., Vo, T., Forbes, C., Zangori, L., \& Schwarz, C. (2019). Impact of model-based science curriculum and instruction on elementary students' explanations for the hydrosphere. Journal of Research in Science Teaching, 56(5), 570597.

Borg, W. R., Gall, J. P., \& Gall, M. D. (2003). Educational research: An introduction. Boston, New York and London. In: Longman.

Cherif, A. H., Roze, M., \& Gialamas, S. (2016). The free classroom creative assignment: Leveraging student strengths to enhance learning. The International Schools Journal, 35(2), 57-66.

Chu, S. K. W., Zhang, Y., Chen, K., Chan, C. K., Lee, C. W. Y., Zou, E., \& Lau, W. (2017). The effectiveness of wikis for project-based learning in different disciplines in higher education. The Internet and Higher Education, 33, 49-60.

Dai, Y. (2019). Situating video conferencing in a connected class toward intercultural knowledge development: A comparative reflection approach. The Internet and Higher Education, 41, 1-10.

Diwakar, S., Radhamani, R., Sujatha, G., Sasidharakurup, H., Shekhar, A., Achuthan, K., Nair, B. (2019). Usage and diffusion of biotechnology virtual labs for enhancing university education in India's urban and rural areas. Breakthroughs in Research and Practic, 3, 433-453.

Erlina, N., Susantini, E., Wasis, Wicaksono, I., \& Pandiangan, P. (2018). The effectiveness of evidence-based reasoning in inquiry-based physics teaching to increase students' scientific reasoning. Journal of Baltic Science Education, 17(6), 972-985.

Glynn, S. M., \& Duit, R. (2012). Learning science meaningfully: Constructing conceptual models. London: Routledge.

Goh, W. W. B., \& Sze, C. C. (2019). AI paradigms for teaching biotechnology. Trends in Biotechnology, 37(1), 1-5.

Hawley, K. (2018). Creativity and knowledge. London: Routledge.

Helms, M. K., Farzaneh, H. H., \& Lindemann, U. (2016). Creating bio-inspired solution ideas using biological research articles. New York, NY: Springer.

Herrington, J., Reeves, T. C., \& Oliver, R. (2014). Authentic learning environments. New York, NY: Springer. 
Hines, M. E., Catalana, S. M., \& Anderson, B. N. (2019). When learning sinks in: Using the incubation model of teaching to guide students through the creative thinking process. Gifted Child Today, 42(1), 36-45.

Hwang, G.-J., Yang, T.-C., Tsai, C.-C., \& Yang, S. J. H. (2009). A context-aware ubiquitous learning environment for conducting complex science experiments. Computers \& Education, 53(2), 402-413.

Jatmiko, B., Prahani, B. K., Supardi, Z. A., Wicaksono, I., Erlina, N., Pandiangan, P., \& Althaf, R. (2018). The comparison of ORIPA teaching model and problem based learning model effectiveness to improve critical thinking skills of pre-service physics teachers. Journal of Baltic Science Education, 17(2), 300-319.

Jatmiko, B., Widodo, W., Martini, B. M., Wicaksono, I., \& Pandiangan, P. (2016). Effectiveness of the INQF-based on learning on a general physics for improving student's learning outcomes. Journal of Baltic Science Education, 15(4), 441-451.

Katok, E. (2018). Designing and conducting laboratory experiments. New York: Jhon Wiley \& Sonc, Inc.

Ketpichainarong, W., Panijpan, B., \& Ruenwongsa, P. (2010). Enhanced learning of biotechnology students by an inquiry-based cellulase laboratory. International Journal of Environmental and Science Education, 5(2), 169-187.

Kim, M. K., Roh, I. S., \& Cho, M. K. (2016). Creativity of gifted students in an integrated math-science instruction. Thinking Skills and Creativity, 19, 38-48.

Lin-Siegler, X., Dweck, C. S., \& Cohen, G. L. (2016). Instructional interventions that motivate classroom learning. Journal of Educational Psychology, 108(3), 295-299.

Maxwell, J. A. (2004). Causal explanation, qualitative research, and scientific inquiry in education. Educational Researcher, 33(2), 3-11.

Mayer, R. E. (2011). Applying the science of learning. Boston, MA: Pearson Allyn \& Bacon.

Moulton, J. M., Cole, C., Ridgers, N. D., Pepin, G., \& Barnett, L. M. (2019). Measuring movement skill perceptions in preschool children: A face validity and reliability study. Australian Occupational Therapy Journal, 66(1), 13-22.

Mustami, M. K., Syamsudduha, S., Safei, \& Ismail, M. I. (2019). Validity, practicality, and effectiveness development of biology textbooks integrated with augmented reality on high school students. International Journal of Technology Enhanced Learning, 11(2), 187-200.

National Research, C. (2007). Taking science to school: Learning and teaching science in grades $K-8$. Washington, D. C: National Academies Press.

Nordqvist, O., \& Aronsson, H. (2019). It is time for a new direction in biotechnology education research. Biochemistry and Molecular Biology Education, 47(2), 189-200.

Orr, M. T., Pecheone, R., Snyder, J. D., Murphy, J., Palanki, A., Beaudin, B., Buttram, J. L. (2018). Performance assessment for principal licensure: Evidence from content and 
face validation and bias review. Journal of Research on Leadership Education, 13(2), 109-138.

Plomp, T. (2013). Educational design research: An introduction. Enschede, the Netherlands: Netherlands Institute for Curriculum Development (SLO).

Roy, P. (2016). Creativity and science education for the gifted: Insights from psychology. London: Routledge.

Sandoval, W. (2014). Science education's need for a theory of epistemological development. Science Education, 98(3), 383-387.

Scanlon, E., Colwell, C., Cooper, M., \& Di Paolo, T. (2004). Remote experiments, reversioning and re-thinking science learning. Computers \& Education, 43(2), 153-163.

Sternberg, R. J. (2018). A triangular theory of creativity. Psychology of Aesthetics, Creativity, and The Arts, 12(1), 50-67.

Suandi, I. K., Aryaningsih, N. N., \& Abdi, I. M. (2018). The implementation of mastery learning concept and cognitive entry behavior to increase the students' competency in accordance with IQF qualification. Journal of Physics: Conference Series IOP, 953(1), 012094-012104.

Swarat, S., Ortony, A., \& Revelle, W. (2012). Activity matters: Understanding student interest in school science. Journal of Research in Science Teaching, 49(4), 515-537.

Taconis, R., Ferguson-Hessler, M. G. M., \& Broekkamp, H. (2001). Teaching science problem solving: An overview of experimental work. Journal of Research in Science Teaching, 38(4), 442-468.

Wechsler, S. M., Saiz, C., Rivas, S. F., Vendramini, C. M. M., Almeida, L. S., Mundim, M. C., \& Franco, A. (2018). Creative and critical thinking: Independent or overlapping components. Thinking Skills and Creativity, 27, 114-122.

Wehmeyer, M. L., Shogren, K. A., Palmer, S. B., Williams-Diehm, K. L., Little, T. D., $\&$ Boulton, A. (2012). The impact of the self-determined learning model of instruction on student self-determination. Exceptional Children, 78(2), 135-153.

Wicaksono, I. (2017). The effectiveness of virtual science teaching model (VS-TM) to Improve Student's Scientific Creativity and Concept Mastery on Senior High School Physics Subject. Journal of Baltic Science Education, 16(4), 549-561

Wicaksono, I., Jatmiko, B., \& Prastowo, T. (2015). Pengembangan perangkat pembelajaran fisika model learning cycle $5 \mathrm{E}$ untuk meningkatkan pemahaman konsep siswa pada materi fluida statis [Development of physical learning tool learning cycle 5E model to improve student concept understanding on static fluid matter]. Jurnal Penelitian Pendidikan Sains, 4(2), 518-524.

Yohana, I., Sudarmin, S., Wardani, S., \& Mohyaddin, S. N. B. (2018). The generic science skill profile of fourth grade students on acid and base topic in guided inquiry learning model. International Journal of Active Learning, 3(2), 110-116.

Zhang, L., Han, Z., \& Gao, Q. (2008). Empirical study on the student satisfaction index in higher education. International Journal of Business and Management, 3(9), 46-51. 